\title{
Academic Supervision: The Efforts to Improve Teachers' Abilities in Implementing Standards of Learning Process
}

\section{Dermawati ${ }^{1}$}

DOI: $10.35445 /$ alishlah.v13i1. 518

\section{Info Artikel}

Keywords: Academic supervision Increased ability Teacher ability Learning process

\section{Abstract}

The aim of the research is to provide information about the standards of the learning process, socialize the standards of the learning process and inform about the implementation of the standard implementation of the learning process for high school teachers in Bandar Lampung. This Research used Qualitative research method. To collect data, the researcher uses observation sheets and documentation. The data analysis technique in this research is using qualitative data analysis. This school action research was designed in two cycles, which consists of planning, implementation, observation, and reflection stages. Data obtained from observations, documentation and portfolios were analyzed in the form of descriptions. The results shows there was a significant increase in each cycle. In some conditions the average value was 59.44 and included in enough category. In the first cycle the average value was 69.72 and was still included in the enough category, while in the first cycle secondly, the average acquisition value was 85.29 and it is still in the good category. From the explanation of the results of the assessment of the 4 aspects of the Implementation of the Learning Activity Process Standards, it shows that in the second cycle all results fall into the good criteria, so it can be concluded that the implementation of school action research is declared complete in the second cycle.

\begin{abstract}
Abstrak
Tujuan dari penelitian ini adalah untuk memberikan informasi tentang standar proses pembelajaran, mensosialisasikan standar proses pembelajaran dan menginformasikan tentang penerapan standar pelaksanaan proses pembelajaran pada guru SMA di Bandar Lampung. Penelitian ini menggunakan metode penelitian kualitatif. Untuk mengumpulkan data, peneliti menggunakan lembar observasi dan dokumentasi. Teknik analisis data dalam penelitian ini menggunakan analisis data kualitatif. Penelitian tindakan sekolah ini dirancang dalam dua siklus, yang terdiri dari tahap perencanaan, pelaksanaan, observasi, dan refleksi. Data yang diperoleh dari observasi, dokumentasi dan portofolio dianalisis dalam bentuk deskripsi. Hasil penelitian menunjukkan adanya peningkatan yang signifikan pada setiap siklusnya. Pada beberapa kondisi nilai rata-rata 59,44 dan termasuk dalam kategori cukup. Pada siklus I nilai rata-rata 69,72 dan masih termasuk dalam kategori cukup, sedangkan pada siklus I nilai rata-rata perolehan sebesar 85,29 dan masih dalam kategori baik. Dari penjelasan hasil penilaian 4 aspek Penerapan Standar
\end{abstract}

${ }^{1}$ Dinas Pendidikan dan Kebudayaan Provinsi Lampung, Lampung, Indonesia

Email: dermawati.arizon@yahoo.com 
Proses Kegiatan Pembelajaran menunjukkan bahwa pada siklus II semua hasil termasuk dalam kriteria baik, sehingga dapat disimpulkan bahwa pelaksanaan penelitian tindakan sekolah. dinyatakan selesai pada siklus kedua

\section{PENDAHULUAN}

Melaksanakan supervisi akademik terhadap kegiatan belajar mengajar (KBM) guru yang dibina adalah salah satu tugas pengawas sekolah. Tujuan pembelajaran dalam sebuah proses pembelajaran adalah hal utama yang harus dicapai. Hal ini dikarenakan tujuan pembelajaran adalah pondasi dasar untuk melihat apakah pembelajaran tersebut berhasil atau tidak. Keberhasilan sebuah kelas pembelajaran dapat dilihat dalam pada hasil pembentukan tingkah laku peserta didik, tentu saja di dalamnya harus terdapat hubungan timbal balik antara pendidik dan peserta didik (Sriwahyuni, N. 2019). Seorang Pengawas Sekolah dalam menjalankan tugas supervisi ini dapat berkolaborasi dengan kepala sekolah dan guru senior. Untuk melaksanakan supervisi akademik akan melibatkan kemampuan kepala sekolah dalam penilaian dan pembinaan guru agar dapat meningkatkan mutu pembelajaran di dalam kelas supaya memberikan efek positif terhadap mutu hasil belajar siswa (Kotirde, 2014).

Kajian tentang supervisi akademik/instruksional telah banyak dilakukan oleh peneliti sebelumnya. Salah satunya menuntun guru untuk meningkatkan potensi diri untuk mencapai tujuan pembelajaran didalam kelas (Kemat, 2016). Supervisi akademik juga membantu guru menjadi guru yang professional untuk siswa (Astuti, 2016). Meningkatkan motivasi guru dapat dilakukan dengan supervisi akademik (Rosilawati, 2014). Dengan adanya kegiatan supervisi akademik sehingga proses pembelajaran akan lebih berenergi (Harahap, 2014). Astuti (2017) menyatakan bahwa kegiatan ini dapat membangkitkan kinerja guru terutama keahlian membuat struktur administrasi penilaian dan kegiatan ini memberikan dampak baik dan signifikan dalam supervisi kepala sekolah dan kinerja guru didalam kelas (Amanda, dkk., 2017). Guru dapat meningkatkan kinerja mereka dengan melakukan supervisi akademik/instruksional dalam melaksanakan pembelajaran (Zakso \& Radiana, 2013). Dengan kata lain, fungsi supervisi akademik tidak hanya menilai kinerja seorang guru dalam mengelola kelas, namun aktifitas seperti ini menuntun guru menjadi profesional dalam mengajar (Bahri, 2014;Rasmita, 2019).

Target supervisi akademik yaitu guru dalam proses pembelajaran yang terdiri dari materi pokok untuk pembelajaran, pembuatan silabus pembelajaran dan Rencana Pelaksanaan Pembelajaran (RPP), penggunaan metode pengajaran dalam pengaplikasian alat maupun media dan teknologi informasi dalam pembelajaran, melalui proses dan hasil pembelajaran serta penelitian tindakan kelas. Tujuan ini dapat diwujudkan dengan adanya kontribusi yang baik bersama kepala sekolah selaku pengawas dan para guru disekolah, dengan ditambah pemberian motivasi serta arahan dari berbagai pihak untuk membuat guru mempunyai keinginan yang kuat dalam memajukan kinerja guru (Zuraidah, 2018).

Tujuan kompetensi akademik adalah mengimplementasikan teknik dan sistem supervisi akademik di sekolah dan meningkatkan keahlian dalam penilaian dan pembinaan guru dalam menaikkan mutu agar lebih baik untuk hasil belajar siswa yang lebih baik. Kemampuan yang harus dimiliki pengawas sekolah yaitu dapat memberikan penilaian dan pembinaan kepada guru secara berkelanjutan untuk menaikkan kualitas proses pembelajaran yang lebih baik. Dalam menggapai kompetensi itu, pengawas melakukan kepengawasan akademik didasarkan pada sistem dan teknik penilaian yang sesuai dengan yang dibutuhkan guru binaan pengawas tersebut. Pengawas memiliki kewajiban dan keterampilan yang dibutuhkan cukup rumit, karena dihadapkan pada kebutuhan fundamental dalam menuntun guru untuk meningkatkan kinerja dalam pengelolaan pembelajaran di kelas.

Keberhasilan sebuah supervisi akademik ada pada kinerja pengawas sekolah dalam menilai tingkat konseptual guru untuk mengembangkan kinerja dalam pengelolaan proses pembelajaran 
demi pencapaian tujuan pembelajaran dan kemudian menerapkan pendekatan berdasarkan tahapannya (Suriati, 2018). Dengan instrument supervisi akademik yang sudah ada dan data dari para guru yang sudah di supervisi, kemudian diberi nilai dan selanjutnya dianalisis dan bagi guru yang mendapatkan hasil yang belum mendapatkan nilai minimum maka akan ditindak lanjuti dan diberi pembinaan oleh pengawas. Dengan merujuk pada media supervisi akademik ini, diharapkan pegawas sekolah dapat melakukan supervisi akademik melalui tahap perencanaan yang baik, pengamatan yang kritis, dan feedback yang efektif seacara berkelanjutan dengan metode pendekatan kemitraan (Samudi, 2018).

Supervisi akademik adalah salah satu tindakan pengembangan untuk para guru ketika melakukan proses pembelajaran dalam menaikkan kemampuan dan mutu hasil pembelajaran (Elliani, 2018). Kegiatan ini adalah tindakan pengembangan yang disusun dengan mengadakan pelatihan teknis untuk guru dalam melaksanan pembelajran, atau mendukung pembelajaran yang bersifat professional. Harapan supervisi akademik yaitu dapat meningktkan tingkat profesionalisme guru dalam mengajar di dalam kelas, namun dalam pelaksanaannya harapan ini belum dapat dicapai. Hal ini disebabkan oleh bermacam masalah yang dipengaruhi oleh aspek struktur birokrasi yang tidak jelas, maupun budaya kerja dan interaksi pengawas dengan guru yang tidak mendukung.

Penelitian ini akan meneliti dan menganalisis hasil pelaksanaan supervisi akademik (pembelajaran) dalam birokrasi pendidikan, dibandingkan dengan konsep-konsep teoritik supervisi seperti di penelitian-penelitian sebelumnya. Penelitian ini terdiri dari dua tahap. Teknik analisis deskriptif dilakukan pada tahap pertama. Peneliti membandingkan hasil pada siklus 1 dan siklus 2 pada tahap kedua. Peneliti akan memberikan saran berdasarkan hasil pada analisa yang dilakukan dalam pelaksanaan supervisi.

\section{METODE}

Penelitian ini menerapkan metode kualitatif. Sehingga, analisis yang digunakan adalah analisis secara kualitatif. Data akan didapatkan dari perolehan pengamatan, bukti, dan portofolio dianalisis ke dalam bentuk deskripsi. Penelitian ini menggunakan analisa kualitatif yang dilakukan secara langsung. Teknik dapat berubah sesuai dengan kondisi pada lapangan (Sukmadinata: 2005, 114). Data yang telah didapatkan kemudian akan dianalisis. Hal ini sesuai dengan permasalahan yang akan dikaji dari tujuan penelitian. Tahap pertama menggunakan teknik analisis deskriptif persentase. Tahap kedua dengan membandingkan antara hasil rekapitulasi nilai siklus I dengan rekapitulasi siklus II.

Metode dalam pengambilan data penelitian ini dilakukan melalui pengamatan dan dokumentasi. Dalam proses pengamatan, peneliti mengamati secara langsung pada hal-hal harus didapatkan pada penelitian ini seperti situasi sosial mengenai tempat, orang, benda-benda, ataupun aktifitas yang sedang berjalan. Peneliti menggunakan standard ketercapaian peningkatan kemampuan guru sebagai acuan dalam kegiatan pengamatan.

Tabel 1.Standard Ketercapaian Peningkatan Kemampuan Guru

\begin{tabular}{cc}
\hline Presentase nilai (\%) & Kualifikasi \\
\hline $86-100$ & Sangat baik \\
\hline $70-85$ & Baik \\
\hline $55-69$ & Cukup \\
\hline$<55$ & Tidak cukup
\end{tabular}

Ketercapaian kenaikan kinerja guru dinilai dari cara guru dalam mengelola kegiatan pembelajaran yang sesuai dengan standar. Hal ini dikatakan sukses apabila mencapai nilai minimal 70\%. Peneliti akan mendapat keterangan dari berbagai data tertulis, foto, dan bahan statistic. Dokumentasi digunakan untuk mengumpulkan hasil belajar anak, foto-foto, video, dan lain sebagainya selama penelitian. Penggunaan dokumentasi dalam penelitian adalah pelengkap dari 
penggunaan metode pengamatan dan tanya jawab sehingga data dapat dianggap valid (Arikunto, 2002 : 206).

Peneliti melakukan tindakan kelas yang berlangsung menggunakan 2 siklus. Tiap siklus memiliki tahapan perencanaan, pelaksanaan, pengamatan, dan refleksi (Aini, 2017). Metode penelitian dengan cara melakukan supervisi akademik yang meliputi supervisi tradisional dan supervisi berkelanjutan yang secara detail dapat diuraikan sebagai berikut: Langkah pertama yang disusun untuk penelitian tindakan langsung meliputi berbagai aktifitas, yaitu mengidentifikasi latar belakang permasalahan, mengajukan proposal penelitian, dan membuat instrument penelitian.

Tabel 2.Siklus Metode Penelitian Tindakan Kelas

\begin{tabular}{|c|c|}
\hline Siklus Pertama & Siklus Kedua \\
\hline Perencanaan & Perencanaan \\
\hline $\begin{array}{l}\text { Untuk tahap awal, peneliti menyusun } \\
\text { kegiatan } \\
\text { memperhatikan beberapa hal dibawah ini: }\end{array}$ & $\begin{array}{l}\text { Untuk perencanaan siklus kedua, peneliti akan } \\
\text { bekerjasama untuk melakukan pertemuan } \\
\text { supervise kelas dan menyiapkan instrumen }\end{array}$ \\
\hline $\begin{array}{l}\text { 1) Menghitung guru yang telah memiliki } \\
\text { silabus dan rencana pelaksanaan } \\
\text { pembelajaran }\end{array}$ & supervisi. \\
\hline 2) Mengecek perangkat pembelajaran guru & \\
\hline 3) Mengecek berkas administrasi guru & \\
\hline $\begin{array}{l}\text { 4) } \begin{array}{l}\text { Menganalisis latar belakang } \\
\text { permasalahan }\end{array} \text { }\end{array}$ & \\
\hline $\begin{array}{l}\text { 5) Membuat tabel rencana kegiatan (berisi } \\
\text { daftar rencana supervisi individual atau } \\
\text { kelompok berdasarkan latar belakang } \\
\text { permasalahan) }\end{array}$ & \\
\hline Pelaksanaan & Pelaksanaan \\
\hline $\begin{array}{l}\text { Peneliti melakukan tindakan supervisi secara } \\
\text { individu atau kelompok. Kegiatan ini } \\
\text { dilakukan untuk menilai berkas administrasi } \\
\text { guru agar peneliti mendapat data yang } \\
\text { mendukung latar belakang permasalahan. } \\
\text { Tahap ini akan dilakukan selama } 2 \text { minggu } \\
\text { dan peneliti akan bekerja sama dengan guru } \\
\text { serta kepala sekolah. }\end{array}$ & $\begin{array}{l}\text { Guru yang telah menyiapkan perangkat } \\
\text { pembelajaran akan langsung disupervisi oleh } \\
\text { peneliti didalam kelas. }\end{array}$ \\
\hline Observasi & Observasi \\
\hline $\begin{array}{l}\text { Untuk tahap ini, peneliti melakukan } \\
\text { pengamatan atas kejadian yang terjadi sejak } \\
\text { awal hingga pelaksanaan tindakan siklus } 1 \text {. }\end{array}$ & $\begin{array}{l}\text { Di tahap observasi siklus kedua, peneliti } \\
\text { mengamati kesinambungan antara } \\
\text { perencanaan rancangan pembelajaran yang } \\
\text { dibuat guru dengan pelaksanaan yang } \\
\text { dilakukan guru didalam kelas, serta melihat } \\
\text { partisipasi siswa dalam proses pembelajaran. }\end{array}$ \\
\hline Refleksi & Refleksi \\
\hline $\begin{array}{l}\text { Tahap ini bertujuan untuk menemukan } \\
\text { solusi dalam meningkatkan kinerja guru. } \\
\text { Peneliti melakukan evaluasi atas kegiatan } \\
\text { maupun data yang telah didapat selama } \\
\text { siklus 1. Lalu peneliti melakukan evaluasi } \\
\text { bersama kepala sekolah dan guru untuk } \\
\text { mempertimbangkan kegiatan siklus } \\
\text { selanjutnya. }\end{array}$ & $\begin{array}{l}\text { Untuk refleksi pada siklus kedua, peneliti } \\
\text { mengevaluasi kegiatan yang dilakukan } \\
\text { bersama guru yang telah disupervisi. Tahap ini } \\
\text { bertujuan untuk menentukan apakah kegiatan } \\
\text { yang dilakukan pada siklus kedua telah } \\
\text { berhasil atau membutuhkan siklus lanjutan. }\end{array}$ \\
\hline
\end{tabular}

Lokasi penelitian adalah di SMA Negeri 12 Bandar Lampung yang beralamat Jalan Hi. Endro Suratmin, Sukarame, Bandar Lampung. Waktu pelaksanaan berlangsung 3 bulan. Subyek yang digunakan adalah 6 guru mata pelajaran di SMA Negeri 12 Bandar Lampung. Adapun objek penelitian adalah peningkatan kemampuan 6 guru SMA Negeri 12 Bandar Lampung dalam Pelaksanaan Standar Proses Kegiatan Pembelajaran. 


\section{HASIL PENELITIAN DAN PEMBAHASAN}

\section{Situasi Awal}

Hasil pengamatan pada situasi awal penelitian diketahui bahwa kemampuan guru SMA Negeri 12 Kota Bandar Lampung dalam pelaksanaan standar proses kegiatan belajar mengajar pada saat sebelum dilakukan tindakan adalah masih dibawah nilai minimum. Hal ini dibuktikan dengan data situasi awal dimana semua instrumen penilaian pelaksanaan standar proses kegiatan pembelajaran menunjukkan hasil yang kurang memuaskan. Sehingga perlu adanya kegiatan perbaikan untuk meningkatkan kemampuan guru dalam pelaksanaan standar proses kegiatan pembelajaran, yaitu dengan melakukan kegiatan supervisi akademik.

Terdapat dua siklus untuk melaksanakan supervisi akademik dan masing-masing siklus memiliki nilai hasil kegiatan supervisi tersebut untuk mengetahui peningkatan kemampuan guru dalam melaksanakan standar proses kegiatan belajar mengajar didalam kelas.

a. Siklus $I$

1. Perencanaan

Untuk memulai siklus 1, peneliti melakukan perencanaan untuk menyiapkan kegiatan yang harus dilakukan. Peneliti mempersiapkan sesi untuk diskusi bersama guru yang membahas masalah yang ada saat menerapkan standar proses kegiatan pembelajaran oleh guru-guru SMA Negeri 12 Bandar Lampung. Setelah itu, peneliti membuat jadwal untuk melakukan kegiatan supervisi.

2. Tindakan

Setelah peneliti membuat kegiatan perencanaan, selanjutnya adalah kegiatan pelaksanaan. Pada kegiatan ini, peneliti akan melakukan beberapa hal untuk mendapatkan data yaitu: pertama, peneliti menganalisis dan membuat strategi untuk mengatasi masalah yang ada saat melaksanakan standar proses kegiatan pembelajaran sesuai dengan hasil diskusi awal. Kedua, pengawas bersama guru menganalisis dokumen pelaksanaan standar proses menggunakan alat penilaian keterampilan guru untuk mengetahui apakah sudah sesuai atau belum. Ketiga, peneliti melalukan penilaian terhadap Rencana Pelaksanaan Pembelajara (RPP). Lalu, guru mencatat hasil yang tidak sesuai dan mencermati butir-butir alat penilaian keterampilan guru. Setelah itu, terdapat diskusi untuk membahas pelaksanaan standar proses kegiatan pembelajaran berdasarkan alat penilaian keterampilan guru tersebut dan standar proses untuk menemukan solusi atas permasalahan yang ada. Penelitian ini berlangsung dalam 2 kali pertemuan tatap muka yang dimulai dengan pelatihan pelaksanaan standar proses kegiatan pembelajaran.

Dari hasil kegiatan siklus 1, peneliti mendapatkan hasil penilaian berdasarkan instrument pelaksanaan standar proses yang telah dibuat dengan tabel dibawah ini:

Tabel 3. Hasil supervisi akademik (RPP) siklus 1

\begin{tabular}{llccccc}
\hline \multirow{2}{*}{ No } & \multirow{2}{*}{ Nama Guru } & Skor & Kualifikasi & \multicolumn{2}{c}{$\begin{array}{c}\text { Peningkatan } \\
\text { Kemampuan }\end{array}$} \\
\cline { 5 - 7 } & & & & $\mathrm{M}$ & $\mathrm{B}$ \\
\hline $\mathbf{1}$ & Sample guru 1 & 74 & $\mathrm{~B}$ & $\sqrt{ }$ & - \\
\hline $\mathbf{2}$ & Sample guru 2 & 68 & $\mathrm{C}$ & - & $\sqrt{ }$ \\
\hline 3 & Sample guru 3 & 70 & $\mathrm{~B}$ & $\sqrt{ }$ & - \\
\hline 4 & Sample guru 4 & 66 & $\mathrm{C}$ & - & $\sqrt{ }$ \\
\hline 5 & Sample guru 5 & 70 & $\mathrm{~B}$ & - & $\sqrt{ }$ \\
\hline 6 & Sample guru 6 & 68 & $\mathrm{C}$ & - & $\sqrt{ }$ \\
\hline & Jumlah & 416,00 & - & 2,00 & 4,00 \\
\hline & rata-rata & 69,33 & $\mathrm{C}$ & - & - \\
\hline & Persentase & - & - & 33,33 & 66,67 \\
\hline
\end{tabular}


Tabel 4. Hasil Supervisi Akademik (Pelaksanaan pembelajaran) Siklus 1

\begin{tabular}{lccccc}
\hline \multirow{2}{*}{ No } & Guru & Skor & Kualifikasi & \multicolumn{2}{c}{$\begin{array}{c}\text { Peningkatan } \\
\text { Kemampuan }\end{array}$} \\
\cline { 5 - 7 } & & & & M & B \\
\hline 1 & Sample guru 1 & 72,14 & B & $\sqrt{ }$ & - \\
\hline 2 & Sample guru 2 & 79,29 & B & $\sqrt{ }$ & - \\
\hline 3 & Sample guru 3 & 69,29 & C & - & $\sqrt{ }$ \\
\hline 4 & Sample guru 4 & 69,29 & C & - & $\sqrt{ }$ \\
\hline 5 & Sample guru 5 & 58,57 & C & - & $\sqrt{ }$ \\
\hline 6 & Sample guru 6 & 68,57 & C & - & - \\
\hline & Jumlah & 417,14 & - & 2,00 & $6,00,67$ \\
\hline & rata-rata & 69,52 & C & - & 33,33 \\
\hline
\end{tabular}

Tabel 5. Hasil Supervisi Akademik (Penilaian hasil belajar) Siklus 1

\begin{tabular}{|c|c|c|c|c|c|}
\hline \multirow[t]{2}{*}{ No } & \multirow[t]{2}{*}{ Nama Guru } & \multirow[t]{2}{*}{ Skor } & \multirow[t]{2}{*}{ Kualifikasi } & \multirow{2}{*}{$\begin{array}{c}\text { Peningkatan } \\
\text { Kemampuan } \\
\mathrm{M}\end{array}$} & \multirow[b]{2}{*}{ B } \\
\hline & & & & & \\
\hline 1 & Sample guru 1 & 63,33 & $\mathrm{C}$ & $\sqrt{ }$ & - \\
\hline 2 & Sample guru 2 & 61,67 & $\mathrm{C}$ & $\sqrt{ }$ & - \\
\hline 3 & Sample guru 3 & 73,33 & B & - & $\sqrt{ }$ \\
\hline 4 & Sample guru 4 & 68,33 & $\mathrm{C}$ & - & $\sqrt{ }$ \\
\hline 5 & Sample guru 5 & 81,67 & B & - & $\sqrt{ }$ \\
\hline \multirow[t]{4}{*}{6} & Sample guru 6 & 80,00 & $\mathrm{~B}$ & - & $\sqrt{ }$ \\
\hline & Jumlah & 428,33 & - & 2,00 & 4,00 \\
\hline & rata-rata & 71,39 & B & - & - \\
\hline & Persentase & - & - & 33,33 & 66,67 \\
\hline
\end{tabular}

Tabel 6. Hasil supervisi akademik (Pengelolaan kelas) siklus 1

\begin{tabular}{llcccc}
\hline \multirow{2}{*}{ No } & Nama Guru & Skor & \multirow{2}{*}{ Kualifikasi } & \multicolumn{2}{c}{$\begin{array}{c}\text { Peningkatan } \\
\text { Kemampuan }\end{array}$} \\
\cline { 5 - 6 } & & & $\mathrm{M}$ & $\mathrm{B}$ \\
\hline $\mathbf{1}$ & Sample guru 1 & 70,00 & $\mathrm{~B}$ & $\sqrt{ }$ & - \\
\hline $\mathbf{2}$ & Sample guru 2 & 66,67 & $\mathrm{C}$ & - & $\sqrt{ }$ \\
\hline 3 & Sample guru 3 & 70,00 & $\mathrm{~B}$ & $\sqrt{ }$ & - \\
\hline 4 & Sample guru 4 & 73,33 & $\mathrm{~B}$ & - & - \\
\hline 5 & Sample guru 5 & 71,67 & $\mathrm{~B}$ & $\sqrt{ }$ & - \\
\hline 6 & Sample guru 6 & 66,67 & $\mathrm{C}$ & - & $\sqrt{ }$ \\
\hline & Jumlah & 418,33 & - & 3,00 & 2,00 \\
\hline & rata-rata & 69,72 & $\mathrm{C}$ & - & - \\
\hline & Persentase & - & - & 50,00 & 33,33 \\
\hline
\end{tabular}

2. Observasi

Dalam kegiatan observasi, peneliti melakukan pemantauan terhadap pelaksanaan kegiatan sebelumnya. Pengawas dan guru melakukan diskusi kembali untuk membahas hasil supervisi yang berdasarkan Permendiknas Nomor 41 Tahun 2007 tentang standar proses dengan menggunakan alat penilaian keterampilan guru.

Berikut ini adalah hasil tindakan siklus 1 meliputi kegiatan RPP, proses pembelajaran, penilaian hasil belajar, dan pengelolaan kelas. 
Tabel 7. Hasil Rekapitulasi Supervisi Akademik pada Siklus 1

\begin{tabular}{lccccc}
\hline \multirow{2}{*}{ No } & \multirow{2}{*}{ Nama Guru } & \multicolumn{4}{c}{ Perolehan Skor } \\
\cline { 3 - 6 } & & $\mathbf{1}$ & $\mathbf{2}$ & 3 & 4 \\
\hline $\mathbf{1}$ & Sample guru 1 & 74,00 & 72,14 & 63,33 & 70,00 \\
\hline $\mathbf{2}$ & Sample guru 2 & 68,00 & 79,29 & 61,67 & 66,67 \\
\hline 3 & Sample guru 3 & 70,00 & 69,29 & 73,33 & 70,00 \\
\hline 4 & Sample guru 4 & 66,00 & 69,29 & 68,33 & 73,33 \\
\hline 5 & Sample guru 5 & 70,00 & 58,57 & 81,67 & 71,67 \\
\hline 6 & Sample guru 6 & 68,00 & 68,57 & 80,00 & 66,67 \\
\hline & Jumlah & 416,00 & 417,14 & 428,33 & 418,33 \\
\hline & Rata-rata & 69,33 & 69,52 & 71,39 & 69,72 \\
\hline
\end{tabular}

Skor Akhir $=$ Jumlah Skor Rata-Rata Jumlah Indikator

\section{Refleksi}

$$
\begin{array}{lll}
= & \frac{279,97}{4} & \\
& 4 & 69,99 \quad \text { (Kualifikasi } \mathrm{C} \text { ) }
\end{array}
$$

Setelah melakukan pengamatan, peneliti membuat pembahasan dan refleksi. Melihat tabel analisis hasil pada siklus 1, peneliti membuat kesimpulan bahwa kinerja guru dalam melakukan standar proses yang berdasarkan Permendiknas No.41 tahun 2007 masuk pada kategori cukup. Berdasarkan hasil tersebut, dapat disimpulkan bahwa guru belum memahami dan belum mampu menerapkan standar proses yang mengacu pada Permendiknas no.41 tahun 2007. Hal ini disebabkan beberapa alasan, yaitu: 1) guru membuat pedoman pelaksanaan standar proses namun belum mencerminkan kegiatan yang dilakukan secara berkelanjutan. 2) indikator pencapaian kompetensi masih belum sesuai. 3) kegiatan proses pembelajaran yang diaplikasikan guru masih kurang beragam sehingga membuat kegiatan terlihat membosankan.

b. Siklus 2

1. Perencanaan

Berdasarkan hasil tindakan siklus 1, hasil belum memenuhi persyaratan kualifikasi yang cukup. Sehingga peneliti melanjutkan tindakan untuk siklus 2. Untuk siklus ini, peneliti mengawali kegiatan berdasarkan hasil analisa pada siklus 1. Tahap perencanaan dibuat berdasarkan peningkatan kinerja guru dalam melaksanakan standar proses kegiatan pembelajaran mengacu pada Permendiknas No.41 tahun 2007. Kegiatan tindakan pada siklus 2 lebih intensif dibanding kegiatan siklus 1 dengan mempertimbangkan hasil analisa dan refleksi sebelumnya.

Dibawah ini adalah tabel data hasil dari pengamatan melalui tindakan pada pelaksanaan standar proses kegiatan pembelajaran dengan pelaksanaan supervise akademik.

Tabel 8. Hasil supervisi akademik (RPP) siklus 2

\begin{tabular}{cccccc}
\hline \multirow{2}{*}{ No } & Nama Guru & Skor & Kualifikasi & \multicolumn{2}{c}{$\begin{array}{c}\text { Peningkatan } \\
\text { Kemampuan }\end{array}$} \\
\cline { 5 - 7 } & & & & M & B \\
\hline 1 & Sample guru 1 & 84 & B & $\sqrt{ }$ & - \\
\hline 2 & Sample guru 2 & 84 & B & $\sqrt{ }$ & - \\
\hline 3 & Sample guru 3 & 90 & BS & $\sqrt{ }$ & - \\
\hline 4 & Sample guru 4 & 84 & B & $\sqrt{ }$ & - \\
\hline 5 & Sample guru 5 & 82 & B & $\sqrt{ }$ & - \\
\hline 6 & Sample guru 6 & 86 & BS & - \\
\hline & Jumlah & 510 & - & 6 & -
\end{tabular}




\begin{tabular}{lcccc}
\hline rata-rata & 85 & B & 100 & 0 \\
\hline Persentase & - & - & 0 & 0 \\
\hline
\end{tabular}

Tabel 9. Hasil Supervisi Akademik (Pelaksanaan Proses Pembelajaran) siklus 2

\begin{tabular}{llccccc}
\hline \multirow{2}{*}{ No } & Nama Guru & Skor & Kualifikasi & \multicolumn{2}{c}{$\begin{array}{c}\text { Peningkatan } \\
\text { Kemampuan }\end{array}$} \\
\cline { 3 - 7 } & & & & M & B \\
\hline 1 & Sample guru 1 & 85,00 & B & $\sqrt{ }$ & - \\
\hline 2 & Sample guru 2 & 90,00 & BS & $\sqrt{ }$ & - \\
\hline 3 & Sample guru 3 & 90,00 & BS & $\sqrt{ }$ & - \\
\hline 4 & Sample guru 4 & 88,57 & BS & $\sqrt{ }$ & - \\
\hline 5 & Sample guru 5 & 85,71 & B & $\sqrt{ }$ & - \\
\hline 6 & Sample guru 6 & 85,71 & B & $\sqrt{ }$ & 0 \\
\hline & Jumlah & 525,00 & - & 6,00 & 0 \\
\hline & rata-rata & 87,50 & BS & 100,00 & 0,00 & 0 \\
\hline & Persentase & - & - & & 0,00
\end{tabular}

Tabel 10. Hasil Supervisi Akademik (Penilaian Hasil Belajar) Siklus 2

\begin{tabular}{llccccc}
\hline \multirow{2}{*}{ No } & NamaGuru & Skor & Kualifikasi & \multicolumn{2}{c}{$\begin{array}{c}\text { Peningkatan } \\
\text { Kemampuan }\end{array}$} \\
\cline { 5 - 7 } & & & & M & B \\
\hline 1 & Sample guru 1 & 81,67 & B & $\sqrt{ }$ & - \\
\hline 2 & Sample guru 2 & 88,33 & BS & $\sqrt{ }$ & - \\
\hline 3 & Sample guru 3 & 81,67 & B & $\sqrt{ }$ & - \\
\hline 4 & Sample guru 4 & 88,33 & BS & $\sqrt{ }$ & - \\
\hline 5 & Sample guru 5 & 88,33 & BS & $\sqrt{ }$ & - \\
\hline 6 & Sample guru 6 & 86,67 & BS & $\sqrt{ }$ & - \\
\hline & Jumlah & 515,00 & - & 6,00 & 0,00 \\
\hline & rata-rata & 85,83 & B & - & - \\
\hline & Persentase & - & - & 100,00 & 0,00 \\
\hline
\end{tabular}

Tabel 11. Hasil Supervisi Akademik (Pengelolaan Kelas) Siklus 2

\begin{tabular}{llccccc}
\hline \multirow{2}{*}{ No } & Nama Guru & Skor & \multirow{2}{*}{ Kualifikasi } & \multicolumn{2}{c}{$\begin{array}{l}\text { Peningkatan } \\
\text { Kemampuan }\end{array}$} \\
\cline { 5 - 7 } & & & & $\mathrm{M}$ & $\mathrm{B}$ \\
\hline $\mathbf{1}$ & Sample guru 1 & 86,67 & $\mathrm{BS}$ & $\sqrt{ }$ & - \\
\hline $\mathbf{2}$ & Sample guru 2 & 83,33 & $\mathrm{~B}$ & $\sqrt{ }$ & - \\
\hline 3 & Sample guru 3 & 81,67 & $\mathrm{~B}$ & $\sqrt{ }$ & - \\
\hline 4 & Sample guru 4 & 86,67 & $\mathrm{BS}$ & $\sqrt{ }$ & - \\
\hline 5 & Sample guru 5 & 88,33 & BS & $\sqrt{ }$ & - \\
\hline 6 & Sample guru 6 & 85,00 & B & $\sqrt{ }$ & - \\
\hline & Jumlah & 511,67 & - & 6,00 & 0,00 \\
\hline & rata-rata & 85,28 & B & - & - \\
\hline & Persentase & - & - & 100,00 & 0,00 \\
\hline
\end{tabular}

Berdasarkan tabel di atas, pada siklus 2 kinerja guru dalam melaksanakan standar proses yang berorientasi pada Permendiknas No. 41 Tahun 2007 telah memiliki nilai diatas minimum, yang mana telah masuk kategori Baik. Siklus 2 diselesaikan dalam 2 kali pertemuan.

2. Observasi 
Pada tahap ini, peneliti melakukan hal yang sama seperti siklus 1 yaitu pemantauan dan pengamatan hasil kegiatan tindakan siklus 2 menggunakan lembar alat penilaian keterampilan guru. Berikut ini adalah hasil tindakan siklus 2 meliputi kegiatan RPP, proses pembelajaran, penilaian hasil belajar, dan pengelolaan kelas.

Tabel 12. Hasil Rekapitulasi Supervisi Akademik pada siklus 2

\begin{tabular}{llcccc}
\hline \multirow{2}{*}{ No } & Nama & \multicolumn{4}{c}{ Perolehan Skor } \\
\cline { 3 - 6 } & Guru & $\mathbf{1}$ & $\mathbf{2}$ & 3 & 4 \\
\hline 1 & Guru 1 & 84,00 & 85,00 & 81,67 & 86,67 \\
\hline 2 & Guru 2 & 84,00 & 90,00 & 88,33 & 83,33 \\
\hline 3 & Guru 3 & 90,00 & 90,00 & 81,67 & 81,67 \\
\hline 4 & Guru 4 & 84,00 & 88,57 & 88,33 & 86,67 \\
\hline 5 & Guru 5 & 82,00 & 85,71 & 88,33 & 88,33 \\
\hline 6 & Guru 6 & 86,00 & 85,71 & 86,67 & 85,00 \\
\hline & Jumlah & 510,00 & 525,00 & 515,00 & 511,67 \\
\hline & Rata-rata & 85,00 & 87,50 & 85,83 & 85,28 \\
\hline
\end{tabular}

Skor Akhir $=$

$$
\begin{aligned}
& \begin{array}{l}
\text { Jumlah Skor Rata-Rata } \\
\text { Jumlah Indikator } \\
= \\
343,61
\end{array} \\
= & 45,90 \quad \text { (Kualifikasi B) }
\end{aligned}
$$

\section{Refleksi}

Setelah menganalisa data yang telah diperoleh, dapat disimpulkan bahwa guru telah mampu melakukan kegiatan standar proses yang berorientasi Permendiknas No.41 tahun 2007. Oleh karena itu, implementasi supervisi akademik dapat meningkatkan kinerja guru dalam melakukan standar proses secara signifikan. Dengan kata lain, guru telah memiliki kategori yang baik dalam melaksanakan standar proses melalui supervisi akademik.

\section{Supervisi Akademik Bidang : Rencana Pelaksanaan Pembelajaran}

Berdasarkan hasil analisis peneliti, pada siklus I dan siklus II terdapat kenaikkan nilai rata-

\begin{tabular}{|c|c|c|c|c|c|c|c|}
\hline \multirow[b]{2}{*}{ No } & \multirow[b]{2}{*}{ Nama Guru } & \multicolumn{3}{|c|}{ Perolehan Skor } & \multicolumn{3}{|c|}{ Kualifikasi Hasil Kinerja } \\
\hline & & Awal & $\begin{array}{c}\text { Siklus } \\
1\end{array}$ & Siklus 2 & Awal & Siklus 1 & Siklus 2 \\
\hline 1 & Sample guru 1 & 58,00 & 74,00 & 84,00 & $\mathrm{C}$ & B & B \\
\hline 2 & Sample guru 2 & 58,00 & 68,00 & 84,00 & $\mathrm{C}$ & $\mathrm{C}$ & $\mathrm{B}$ \\
\hline 3 & Sample guru 3 & 66,00 & 70,00 & 90,00 & $\mathrm{C}$ & B & $\mathrm{BS}$ \\
\hline 4 & Sample guru 4 & 60,00 & 66,00 & 84,00 & $\mathrm{C}$ & $\mathrm{C}$ & $\mathrm{B}$ \\
\hline 5 & Sample guru 5 & 62,00 & 70,00 & 82,00 & $\mathrm{C}$ & B & B \\
\hline \multirow[t]{3}{*}{6} & Sample guru 6 & 56,00 & 68,00 & 86,00 & $\mathrm{C}$ & $\mathrm{C}$ & BS \\
\hline & Jumlah & 360,00 & 416,00 & 510,00 & - & - & - \\
\hline & Rata-rata & 60,00 & 69,33 & 85,00 & $\mathrm{C}$ & $\mathrm{C}$ & B \\
\hline
\end{tabular}
rata dan kualifikasi kinerja guru untuk menyusun RPP yang berorientasi pada Permendiknas No.41 tahun 2007.

Tabel 13. Rekapitulasi Hasil Supervisi Akademik (RPP) pada situasi awal, siklus 1, dan siklus 2 
Tabel 14. Hasil Supervisi Akademik (RPP) pada situasi awal, siklus 1, dan siklus 2

\begin{tabular}{llccc}
\hline \multirow{2}{*}{ No } & \multirow{2}{*}{ Nama Guru } & \multicolumn{3}{c}{ Perolehan Skor } \\
\cline { 2 - 5 } & & Awal & Siklus 1 & Siklus 2 \\
\hline 1 & Sample guru 1 & 58,00 & 74,00 & 84,00 \\
\hline 2 & Sample guru 2 & 58,00 & 68,00 & 84,00 \\
\hline 3 & Sample guru 3 & 66,00 & 70,00 & 90,00 \\
\hline 4 & Sample guru 4 & 60,00 & 66,00 & 84,00 \\
\hline 5 & Sample guru 5 & 62,00 & 70,00 & 82,00 \\
\hline 6 & Sample guru 6 & 56,00 & 68,00 & 86,00 \\
\hline & Jumlah & 360,00 & 416,00 & 510,00 \\
\hline & Rata-rata & 60,00 & 69,33 & 85,00 \\
\hline
\end{tabular}

Skor Akhir $=\quad$ Jumlah Skor Rata-Rata

Jumlah Indikator

$=\underline{\mathbf{2 1 4}}, 33$

3

$=\quad 71,44 \quad$ (Kualifikasi B)

Berdasarkan data ini, untuk melihat peningkatan kemampuan guru dalam membuat RPP yang berorientasi pada Permendiknas No. 41 Tahun 2007 dapat dilihat melalui ilustrasi grafik dibawah ini :

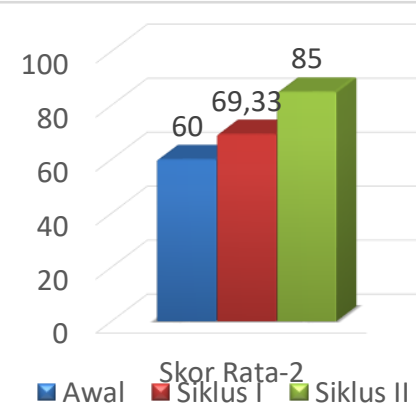

Figure 1. Hasil Rata-rata Supervisi Akademik (RPP) pada Siklus 1 dan Siklus 2 Supervisi Akademik Bidang: Pelaksanaan Proses Pembelajaran

Berdasarkan hasil supervisi akademik (Pelaksanaan proses pembelajaran) sejak situasi awal, siklus 1, dan siklus 2 terdapat peningkatan nilai rata-rata dan kualifikasi kinerja guru yang berorientasi pada Permendiknas No.41 tahun 2007. Dibawah ini adalah hasil analisis data.

Tabel 15. Hasil Rekapitulasi Supervisi Akademik (Pelaksanaan Proses Pembelajaran) ketika Kondisi Awal, Siklus 1, dan Siklus 2

\begin{tabular}{llcccccc}
\hline \multirow{2}{*}{ No } & \multirow{2}{*}{ Nama Guru } & \multicolumn{3}{c}{ Perolehan Skor } & \multicolumn{3}{c}{ Kualifikasi Hasil Kinerja } \\
\cline { 3 - 8 } & & Awal & $\begin{array}{c}\text { Siklus } \\
\mathbf{1}\end{array}$ & Siklus 2 & Awal & Siklus 1 & Siklus 2 \\
\hline $\mathbf{1}$ & Sample guru 1 & 58,57 & 72,14 & 85,00 & $\mathrm{C}$ & $\mathrm{B}$ & $\mathrm{B}$ \\
\hline $\mathbf{2}$ & Sample guru 2 & 57,86 & 79,29 & 90,00 & $\mathrm{C}$ & $\mathrm{B}$ & $\mathrm{BS}$ \\
\hline 3 & Sample guru 3 & 59,29 & 69,29 & 90,00 & $\mathrm{C}$ & $\mathrm{C}$ & $\mathrm{BS}$ \\
\hline 4 & Sample guru 4 & 60,00 & 69,29 & 88,57 & $\mathrm{C}$ & $\mathrm{C}$ & $\mathrm{BS}$ \\
\hline 5 & Sample guru 5 & 57,14 & 58,57 & 85,71 & $\mathrm{C}$ & $\mathrm{C}$ & $\mathrm{B}$ \\
\hline 6 & Sample guru 6 & 58,57 & 68,57 & 85,71 & $\mathrm{C}$ & $\mathrm{C}$ & $\mathrm{B}$ \\
\hline & Jumlah & 351,43 & 417,14 & 525,00 & - & - & - \\
\hline & Rata-rata & 58,57 & 69,52 & 87,50 & $\mathrm{C}$ & $\mathrm{C}$ & BS \\
\hline
\end{tabular}


Tabel 16. Hasil Supervisi Akademik (Pelaksanaan Proses Pembelajaran) situasi awal, siklus 1, dan siklus 2

\begin{tabular}{llccc}
\hline \multirow{2}{*}{ No } & \multirow{2}{*}{ Nama Guru } & \multicolumn{3}{c}{ Perolehan Skor } \\
\cline { 3 - 5 } & & Awal & Siklus 1 & Siklus 2 \\
\hline 1 & Sample guru 1 & 58,57 & 72,14 & 85 \\
\hline 2 & Sample guru 2 & 57,86 & 79,29 & 90 \\
\hline 3 & Sample guru 3 & 59,29 & 69,29 & 90 \\
\hline 4 & Sample guru 4 & 60 & 69,29 & 88,57 \\
\hline 5 & Sample guru 5 & 57,14 & 58,57 & 85,71 \\
\hline 6 & Sample guru 6 & 58,57 & 68,57 & 85,71 \\
\hline & Jumlah & 351,43 & 417,15 & 524,99 \\
\hline & Rata-rata & 58,57 & 69,53 & 87,50 \\
\hline
\end{tabular}

$$
\begin{aligned}
\text { Skor Akhir } & =\quad \frac{\text { Jumlah skor rata-rata }}{\text { Jumlah Indikator }} \\
& =\quad 214.33 \\
& =71,87 \quad \text { (Kualifikasi B) }
\end{aligned}
$$

Dari penjelasan pada tabel di atas, untuk memperjelas peningkatan kemampuan guru dalam menyusun Pelaksanaan Proses Pembelajaran yang mengacu pada Permendiknas No. 41 Tahun 2007 sebagaima grafik di bawah ini:
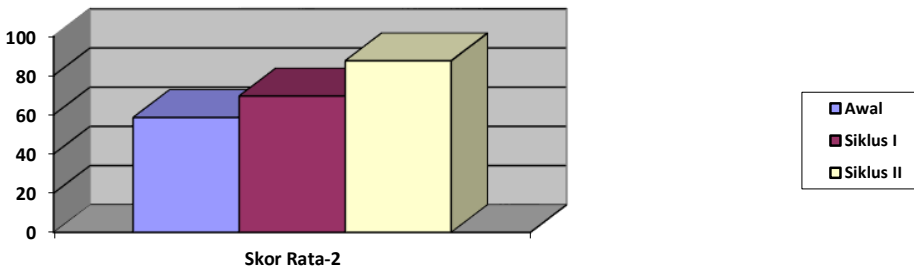

Gambar 2. Peningkatan Hasil Supervisi Akademik (Pelaksanaan proses pembelajaran) pada situasi awal, siklus 1, dan siklus 2

\section{Supervisi Akademik Bidang : Penilaian Hasil Belajar}

Dari kedua siklus yang telah dilakukan terdapat peningkatan nilai rata-rata dan kualifikasi kinerja guru dalam Penilaian Hasil Belajar yang berorientasi dengan Permendiknas No. 41 Tahun 2007. Data analisis ditampilkan melalui tabel dibawah ini:

Tabel 17.Rekapitulasi Hasil Supervisi Akademik (Penilaian Hasil Belajar) pada situasi Awal, siklus 1, dan siklus 2

\begin{tabular}{cccccccc}
\hline \multirow{2}{*}{ No } & \multirow{2}{*}{ Nama Guru } & \multicolumn{3}{c}{ Perolehan Skor } & \multicolumn{2}{c}{ Kualifikasi Hasil Kinerja } \\
\cline { 3 - 8 } & & Awal & $\begin{array}{c}\text { Siklus } \\
\mathbf{1}\end{array}$ & Siklus 2 & Awal & Siklus 1 & Siklus 2 \\
\hline $\mathbf{1}$ & Sample guru 1 & 58,33 & 63,33 & 81,67 & $\mathrm{C}$ & $\mathrm{C}$ & $\mathrm{B}$ \\
\hline $\mathbf{2}$ & Sample guru 2 & 60,00 & 61,67 & 88,33 & $\mathrm{C}$ & $\mathrm{C}$ & $\mathrm{BS}$ \\
\hline 3 & Sample guru 3 & 60,00 & 73,33 & 81,67 & $\mathrm{C}$ & $\mathrm{B}$ & $\mathrm{B}$ \\
\hline 4 & Sample guru 4 & 58,33 & 68,33 & 88,33 & $\mathrm{C}$ & $\mathrm{C}$ & $\mathrm{BS}$ \\
\hline 5 & Sample guru 5 & 60,00 & 81,67 & 88,33 & $\mathrm{C}$ & $\mathrm{B}$ & $\mathrm{BS}$ \\
\hline 6 & Sample guru 6 & 61,67 & 80,00 & 86,67 & $\mathrm{C}$ & $\mathrm{B}$ & $\mathrm{BS}$ \\
\hline & Jumlah & 358,33 & 428,33 & 515,00 & - & - & - \\
\hline & Rata-rata & 59,72 & 71,39 & 85,83 & $\mathrm{C}$ & $\mathrm{B}$ & $\mathrm{B}$ \\
\hline
\end{tabular}




\section{Tabel 18.Hasil Supervisi Akademik (Penilaian Hasil Belajar)} pada situasi awal, siklus 1 dan siklus 2

\begin{tabular}{|c|c|c|c|c|}
\hline \multirow{2}{*}{ No } & \multirow{2}{*}{ Nama Guru } & \multicolumn{3}{|c|}{ Perolehan Skor } \\
\hline & & Awal & Siklus 1 & Siklus 2 \\
\hline 1 & Sample guru 1 & 58,33 & 63,33 & 81,67 \\
\hline 2 & Sample guru 2 & 60,00 & 61,67 & 88,33 \\
\hline 3 & Sample guru 3 & 60,00 & 73,33 & 81,67 \\
\hline 4 & Sample guru 4 & 58,33 & 68,33 & 88,33 \\
\hline 5 & Sample guru 5 & 60,00 & 81,67 & 88,33 \\
\hline \multirow[t]{3}{*}{6} & Sample guru 6 & 61,67 & 80,00 & 86,67 \\
\hline & Jumlah & 358,33 & 428,33 & 515,00 \\
\hline & Rata-rata & 59,72 & 71,39 & 85,83 \\
\hline
\end{tabular}

Skor Akhir $=$ Jumlah Skor Rata-Rata

$$
\begin{aligned}
& =\quad \frac{\text { Jumlah Indikator }}{316,94} \\
& =\quad 72,31 \quad \text { (Kualifikasi B) }
\end{aligned}
$$

Berdasarkan nilai pada tabel diatas, untuk memperjelas peningkatan kemampuan guru dalam membuat Penilaian Hasil Belajar yang berorientas pada Permendiknas No. 41 Tahun 2007 sebagaima grafik di bawah ini :
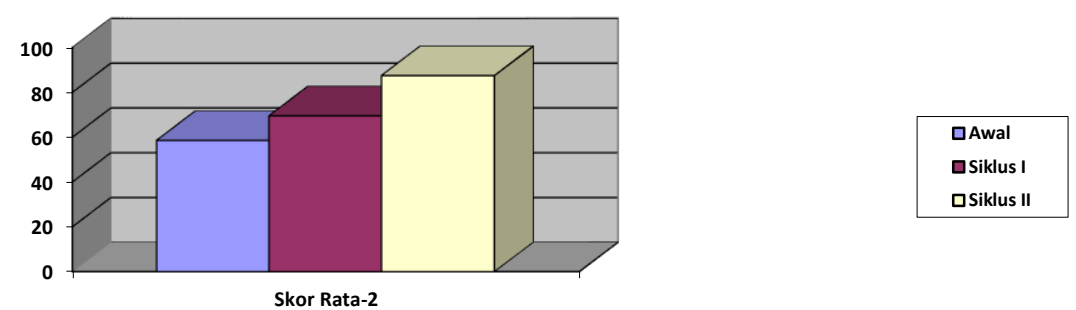

\section{Gambar 3. Peningkatan Hasil Supervisi Akademik (Penilaian Hasil Belajar) pada situasi awal, siklus 1, dan siklus 2}

\section{Supervisi Akademik Bidang : Pengelolaan Kelas}

Dapat dilihat adanya peningkatan rata-rata dan kriteria kemampuan guru dalam Pengelolaan Kelas yang mengacu pada Permendiknas No. 41 Tahun 2007. Dari hasil analisis data diperoleh hasil sebagai berikut:

Tabel 19.Rekapitulasi Hasil Supervisi Akademik (Pengelolaan Kelas) pada situasi awal, siklus 1, dan siklus 2

\begin{tabular}{llcccccc}
\hline \multirow{2}{*}{ No } & \multirow{2}{*}{ Nama Guru } & \multicolumn{3}{c}{ Perolehan Skor } & \multicolumn{2}{c}{ Kualifikasi Hasil Kinerja } \\
\cline { 3 - 8 } & & Awal & $\begin{array}{c}\text { Siklus } \\
\mathbf{1}\end{array}$ & Siklus 2 & Awal & $\begin{array}{c}\text { Siklus } \\
\mathbf{1}\end{array}$ & Siklus 2 \\
\hline $\mathbf{1}$ & Sample guru 1 & 56,67 & 70,00 & 86,67 & $\mathrm{C}$ & $\mathrm{B}$ & $\mathrm{BS}$ \\
\hline $\mathbf{2}$ & Sample guru 2 & 58,33 & 66,67 & 83,33 & $\mathrm{C}$ & $\mathrm{C}$ & $\mathrm{B}$ \\
\hline 3 & Sample guru 3 & 61,67 & 70,00 & 81,67 & $\mathrm{C}$ & $\mathrm{B}$ & $\mathrm{B}$ \\
\hline 4 & Sample guru 4 & 58,33 & 73,33 & 86,67 & $\mathrm{C}$ & $\mathrm{B}$ & $\mathrm{BS}$ \\
\hline 5 & Sample guru 5 & 61,67 & 71,67 & 88,33 & $\mathrm{C}$ & $\mathrm{B}$ & $\mathrm{BS}$ \\
\hline 6 & Sample guru 6 & 60,00 & 66,67 & 85,00 & $\mathrm{C}$ & $\mathrm{C}$ & $\mathrm{B}$ \\
\hline & Jumlah & 356,67 & 418,33 & 511,67 & - & - & - \\
\hline & Rata-rata & 59,44 & 69,72 & 85,28 & $\mathrm{C}$ & $\mathrm{C}$ & $\mathrm{B}$ \\
\hline
\end{tabular}


Tabel 2o. Hasil Supervisi Akademik (Pengelolaan Kelas) pada situasi awal, siklus ,1 dan siklus 2

\begin{tabular}{|c|c|c|c|c|c|}
\hline \multirow{2}{*}{ No } & \multirow{2}{*}{ Nama Guru } & \multicolumn{3}{|c|}{ Perolehan Skor } & \multirow{2}{*}{ Ket } \\
\hline & & Awal & Siklus 1 & Siklus 2 & \\
\hline 1 & Sample guru 1 & 56,67 & 70,00 & 86,67 & \\
\hline 2 & Sample guru 2 & 58,33 & 66,67 & 83,33 & \\
\hline 3 & Sample guru 3 & 61,67 & 70,00 & 81,67 & \\
\hline 4 & Sample guru 4 & 58,33 & 73,33 & 86,67 & \\
\hline 5 & Sample guru 5 & 61,67 & 71,67 & 88,33 & \\
\hline \multirow[t]{3}{*}{6} & Sample guru 6 & 60,00 & 66,67 & 85,00 & \\
\hline & Jumlah & 356,67 & 418,33 & 511,67 & \\
\hline & Rata-rata & 59,44 & 69,72 & 85,28 & \\
\hline
\end{tabular}

$$
\begin{aligned}
\text { Skor Akhir } & =\frac{\text { Jumlah Skor Rata-Rata }}{\text { Jumlah Indikator }} \\
& =\underline{214,44} \\
& =71,48 \quad \text { (Kualifikasi B) }
\end{aligned}
$$

Dari penjelasan pada tabel di atas, untuk memperjelas peningkatan kemampuan guru dalam Pengelolaan Kelas yang mengacu pada Permendiknas No. 41 Tahun 2007 sebagaima grafik di bawah ini :
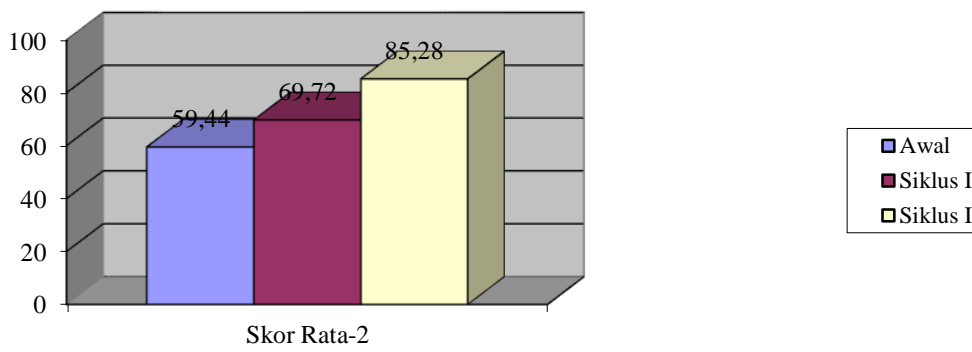

Gambar 4. Peningkatan Hasil Supervisi Akademik (pengelolaan kelas) pada situasi awal, siklus 2, dan siklus 2

Pelaksanaan penelitian tindakan ini menerapkan supervisi akademik menunjukkan hasil yang baik dan mencapai kualifikasi yang ditentukan. Terdapat peningkatan kinerja guru dalam melaksanakan standar proses yang meliputi bidang Rencana Pelaksanaan Pembelajaran (RPP), pelaksanaan proses pembelajaran, penilaian hasil belajar, dan pengelolaan kelas. Hal ini sejalan dengan penelitian yang dilakukan oleh Jurianti (2018) bahwa keterampilan mengajar guru pada mata pelajaran IPS mengalami peningkatan setelah diterapkan supervisi akademik. Zuraida (2018) menyatakan bahwa kinerja guru dalam menyusun perencanaan pembelajaran akan meningkat setelah menerapkan supervisi akademik oleh pengawas secara berkelanjutan. Suriati (2011) menyatakan bahwa dengan adanya supervisi yang dilakukan oleh kepala sekolah mampu memberikan dampak positif dalam kemampuan mengajar guru. Rasmita (2019) mendukung bahwa kualitas pembelajaran di SD Negeri o17 Pasir meningkat setelah adanya supervisi akademik. Berdasarkan beberapa hasil penelitian tersebut maka supervisi akademik meningkatkan kinerja atau kompetensi guru baik dalam menyusun perencanaan pembelajaran dan pelaksanaan proses pembelajaran.

\section{SIMPULAN}

Supervisi akademik yang dilakukan secara terus-menerus terbukti secara ilmiah dapat meningkatkan kinerja guru dalam pelaksanaan standar proses kegiatan pembelajaran di SMA Negeri 12 Bandar Lampung. Hal ini dibuktikan dengan adanya peningkatan nilai terhadap 
kemampuan guru dalam pelaksanaan standar proses kegiatan pembelajaran pada tiap-tiap aspek penilaian, yakni Penilaian Bidang Rencana Pelaksanaan Pembelajaran; Penilaian Bidang Pelaksanaan Proses Pembelajaran; Penilaian Bidang Penilaian Hasil Belajar; dan Penilaian Bidang Pengawasan Proses Pembelajaran. Dari penjelasan hasil penilaian terhadap 4 aspek Pelaksanaan Standar Proses Kegiatan Pembelajaran menunjukkan bahwa pada siklus kedua semua hasil masuk dalam kriteria Baik. Dapat disimpulkan bahwa pelaksanaan penelitian tindakan sekolah dinyatakan selesai pada siklus kedua dan tidak diperlukan siklus tambahan.

Metode supervisi yang membuat adanya peningkatan kinerja guru untuk melaksanaan standar proses kegiatan pembelajaran tersebut yakni pengumuman rencana supervisi terhadap guru, pelaksanaan supervisi individual, dimana setiap guru diminta mempresentasikan silabus dan RPP kepada kepala sekolah, kemudian kepala sekolah memberikan masukan terhadap kekurangan silabus dan RPP guru dan pelaksanaan supervisi individual yang dilakukan oleh kepala sekolah untuk memeriksa silabus dan RPP yang disusun guru. Penelitian ini hanya terbatas dilakukan di SMAN 12 Bandar Lampung, namun penelitian ini dapat dijadikan rujukan bagi peneliti lainnya mengenai bagaimana cara peningkatan kinerja guru dalam pelaksanaan standar proses kegiatan pembelajaran melalui supervisi akademik. Metode dan hasil penelitian ini dapat dijadikan rujukan untuk sekolah lain yang ada di Kota Bandar Lampung ataupun di sekolah sekolah lain di Indonesia.

\section{DAFTAR PUSTAKA}

Aini, Baiq (2017). Upaya Meningkatkan Kompetensi Guru Dalam Proses Pembelajaran Berdasarkan Kurikulum 2013 Melalui Supervisi Akademik Semester Satu Tahun Pelajaran 2017/2018 Di SD Negeri 5 Mataram. Jurnal Pendidikan Mandala. 2 (2), 1-12.

Amanda, M. O., Salam, R., \& Saggaf, S. (2017). Pengaruh Supervisi Kepala Sekolah Terhadap Kinerja Guru di SMK Negeri 1 Bungoro Kabupaten Pangkep. In Prosiding Seminar Nasional Himpunan Sarjana Ilmu-Ilmu Sosial. 2 (1), 149-154.

Arikunto, S. (2006).Prosedur Penelitian (Suatu Pendekatan Praktek). Jakarta. PT Rineka Cipta.

Astuti.S. (2016). Penerapan Supervisi Akademik untuk Meningkatkan Kompetensi Guru dalam Menyusun Administrasi Penilaian di SD Laboratorium UKSW. Scholaria :Jurnal Pendidikan dan Kebudayaan. 6 (1), 117-126

Astuti, S. (2017). Supervisi Akademik Untuk Meningkatkan Kompetensi Guru di SD Laboratorium UKSW. Scholaria: Jurnal Pendidikan dan Kebudayaan, 7(1), 49-59.

Bahri, S. (2014).Supervisi Akademik Dalam Peningkatan Profesionalisme Guru.Visipena Journal 5(1), 100-112.

Elliani, F. (2018). Pelaksanaan Supervisi Akademik Untuk Meningkatkan Kompetensi Guru Dalam Menyusun Rencana Pelaksanaan Pembelajaran (Studi Di Sd Negeri Lamklat Kecamatan Darussalam Kabupaten Aceh Besar). At-Ta'dib: Jurnal Ilmiah Pendidikan Agama Islam, 10 (2), 174-181.

Glickman, C.D., Gordon, S.P., and RossGordon, J.M. (2007).Supervision and Instructional Leadership A Development Approach. Seventh Edition. Boston: Perason

Harahap, D. P. (2014).Supervisi Akademik Teknik Workshop Meningkatkan Kemampuan Guru Melaksanakan Pembelajaran Aktif. Jurnal Manajemen Pendidikan Indonesia, 6 (o2), 67-76.

Jurianti.(2018). Peningkatan Keterampilan Mengajar Guru Pada Mata Pelajaran IPS Melalui Supervisi Akademik SD Negeri o38 Pulau Kijang.Jurnal PAJAR (Pendidikan dan Pengajaran), 2 (6), 928- 935.

Kemat, (2016).Penerapan Supervisi Akademik Untuk Meningkatkan Kemampuan Guru Dalam Merencanakan dan Melaksanakan Pembelajaran.Manajer Pendidikan. 10 (6), 622-627. 
Kotirde,I.Y. (2014). The Supervisor's role for improving the quality of teaching and learning in Nigeria secondary school educational system.International Journal of Education and research. 2 (8),53-60.

Rasmita, D. (2019). Upaya Meningkatan Kompetensi Guru Dalam Pelaksanaan Proses Pembelajaran Melalui Supervisi Akademik Di Sd Negeri 017 Pasir Emas. Jurnal PAJAR (Pendidikan dan Pengajaran). 3 (3).560-569.

Satori, D. Komariah, A. (2012).Metodologi Penelitian Kualitatif. Bandung. Alfabeta.

Sriwahyuni, N. (2019). Peningkatan Kemampuan Guru Dalam Proses Pembelajaran Berkualitas Melalui Supervisi Akademik Dengan Teknik Kunjungan Kelas pada Guru Sekolah Dasar.Jurnal Pendidikan Dasar. 7 (1), 51-57.

Samudi.(2018). Penerapan Supervisi Akademik Sebagai Upaya Untuk Meningkatkan Kinerja Guru Sekolah Dasar.Jurnal PAJAR (Pendidikan dan Pengajaran), 1 (1), 142- 149.

Suriati.(2018). Meningkatkan Kompetensi Guru SDN oo7 Kampung Baru Kecamatan Cerenti dalam Menyusun Perencanaan Pembelajaran Melalaui Supervisi Akademik.Jurnal PAJAR (Pendidikan dan Pengajaran), 2 (2), 269-281,

Wartini. (2018). Upaya Peningkatan Kompetensi Guru dalam Melaksanakan Proses Belajar Mengajar Melalui Supervisi Akademik di SDN o11 Bukit Raya Singingi Hilir Kecamatan Singingi Hilir. Jurnal PAJAR (Pendidikan dan Pengajaran), 2 (6), 1023- 1031.

Zakso, A., \& Radiana, U. (2013).Pelaksanaan Supervisi Akademik Pengawas Sekolah Sebagai Upaya Peningkatan Profesionalisme Guru SMP Negeri 1 Bengkayang.Jurnal Pendidikan dan Pembelajaran, 2(3), 1-16.

Zuraida.(2018). Penerapan Supervisi Akademis Pengawas Sekolah untuk Meningkatkan Kompetensi Pedagogik Guru Non Kependidikan SDN oo3 Bagan Hulu Kecamatan Bangko Kabupaten Rokan Hilir.Jurnal PAJAR (Pendidikan dan Pengajaran), 1 (1), 136-141. 